\title{
Fine roots stimulate nutrient release during early stages of leaf litter decomposition in a Central Amazon rainforest
}

\author{
Nathielly P. Martins (D) Lucia Fuchslueger (D) Katrin Fleischer (D) Kelly M. Andersen (D) \\ Rafael L. Assis (D) Fabricio B. Baccaro (D) Plínio B. Camargo (D) Amanda L. Cordeiro (D) \\ Adriana Grandis (1) - Iain P. Hartley (D) Florian Hofhansl (i) - Laynara F. Lugli (1) David M. Lapola (D)

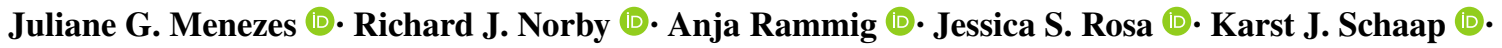 \\ Bruno Takeshi (D) Oscar J. Valverde-Barrantes (D) Carlos A. Quesada
}

Received: 8 February 2021 / Accepted: 6 September 2021 / Published online: 2 October 2021

(C) The Author(s) 2021, corrected publication 2022

\begin{abstract}
Purpose Large parts of the Amazon rainforest grow on weathered soils depleted in phosphorus and rockderived cations. We tested the hypothesis that in this ecosystem, fine roots stimulate decomposition and nutrient release from leaf litter biochemically by releasing enzymes, and by exuding labile carbon stimulating microbial decomposers.
\end{abstract}

Responsible Editor: Michael Luke McCormack.

Supplementary Information The online version contains supplementary material available at https://doi. org/10.1007/s11104-021-05148-9.

N. P. Martins $(\varangle) \cdot$ L. Fuchslueger $(\varangle) \cdot$ R. L. Assis ·

A. L. Cordeiro - L. F. Lugli · J. G. Menezes · J. S. Rosa ·

K. J. Schaap · B. Takeshi · C. A. Quesada

Coordination of Environmental Dynamics (CODAM),

National Institute of Amazonian Research, Manaus, Brazil

e-mail: nathiellymartins9@gmail.com

L. Fuchslueger

e-mail: lucia.fuchslueger@univie.ac.at

L. Fuchslueger

Centre of Microbiology and Environmental Systems

Sciences, University of Vienna, Vienna, Austria

K. Fleischer · A. Rammig

Technical University of Munich, TUM School of Life

Sciences Weihenstephan, Freising, Germany

K. Fleischer

Department Biogeochemical Signals, Max-Planck-Institute

for Biogeochemistry, Jena, Germany
Methods We monitored leaf litter decomposition in a Central Amazon tropical rainforest, where fine roots were either present or excluded, over 188 days and added labile carbon substrates (glucose and citric acid) in a fully factorial design. We tracked litter mass loss, remaining carbon, nitrogen, phosphorus and cation concentrations, extracellular enzyme activity and microbial carbon and nutrient concentrations.

Results Fine root presence did not affect litter mass loss but significantly increased the loss of phosphorus and cations from leaf litter. In the presence of fine roots, acid phosphatase activity was $43.2 \%$ higher, while neither microbial stoichiometry, nor extracellular enzyme

\section{K. M. Andersen}

Nanyang Technological University, Asian School

of the Environment, Singapore, Singapore

R. L. Assis

Natural History Museum, University of Oslo, Oslo,

Norway

\section{F. B. Baccaro}

Department of Biology, Federal University of Amazonas, Manaus, Brazil

P. B. Camargo

Center of Nuclear Energy in Agriculture (CENA), University of São Paulo, Piracicaba, Brazil

\author{
A. L. Cordeiro \\ Colorado State University - CSU, Fort Collins, CO, USA
}


activities targeting carbon- and nitrogen-containing compounds changed. Glucose additions increased phosphorus loss from litter when fine roots were present, and enhanced phosphatase activity in root exclusions. Citric acid additions reduced litter mass loss, microbial biomass nitrogen and phosphorus, regardless of fine root presence or exclusion.

Conclusions We conclude that plant roots release significant amounts of acid phosphatases into the litter layer and mobilize phosphorus without affecting litter mass loss. Our results further indicate that added labile carbon inputs (i.e. glucose) can stimulate acid phosphatase production by microbial decomposers, highlighting the potential importance of plantmicrobial feedbacks in tropical forest ecosystems.

Keywords Amazon rainforest · Litter decomposition $\cdot$ Fine roots $\cdot$ Acid phosphatase $\cdot$ Root exudates $\cdot$ Labile carbon

\section{Introduction}

The tropical rainforest in the Amazon Basin is one of the most productive forest ecosystems in the world and contributes about a quarter to the global terrestrial carbon (C) sink, playing an immense role in offsetting anthropogenic $\mathrm{CO}_{2}$ emissions (Pan et al. 2011; Quéré et al. 2018; Hubau et al. 2020). However, about $60 \%$ of the rainforest in the Amazon basin is growing on soils strongly depleted in phosphorus (P) and other bedrock-derived cations (Quesada et al. 2010). Limited $\mathrm{P}$ availability could reduce or eliminate the predicted

A. Grandis

Department of Botany, Biosciences Institute, University of São Paulo, São Paulo, Brazil

\section{P. Hartley}

Geography, College of Life and Environmental Sciences, University of Exeter, Exeter, UK

\section{F. Hofhansl}

Biodiversity, Ecology, and Conservation (BEC), Research Group Biodiversity and Natural Resources (BNR) Program, International Institute for Applied Systems Analysis (IIASA), Laxenburg, Austria

D. M. Lapola

Center for Climatic and Meteorological Research Applied to Agriculture (CEPAGRI), University of Campinas

(UNICAMP), Campinas, Brazil stimulatory effect of elevated $\mathrm{CO}_{2}\left(\mathrm{eCO}_{2}\right)$ on plant productivity, since plants can increase $\mathrm{C}$ uptake and growth only if they are able to sustain the associated higher nutrient demand (Terrer et al. 2019). Under $\mathrm{eCO}_{2}$ plants can increase belowground $\mathrm{C}$ allocation, i.e. increase fine root productivity, enzyme or labile $\mathrm{C}$ exudation to maintain plant nutrient uptake (Iversen et al. 2008; Phillips et al. 2011; Jiang 2020). However, scarce direct observations of the effects of $\mathrm{eCO}_{2}$ on tropical plant $\mathrm{P}$ uptake result in high uncertainties in the representation of potential interactions and plantsoil feedbacks in process-based ecosystem models for tropical forests (Fleischer et al. 2019; Du et al. 2020). Thus, it is crucial to acquire a better understanding of plant and soil interactions to predict the response of tropical forest ecosystems to $\mathrm{eCO}_{2}$ in a more realistic way (Cernusak et al. 2013; Hofhansl et al. 2016).

Plants have developed various morphological and physiological adaptations in their fine root systems to optimize nutrient uptake; they can produce long and thin roots, establish symbiotic associations with mycorrhizal fungi facilitating the uptake of scarce nutrients and direct their growth to nutrient rich soil patches (Lambers et al. 2015; McCormack and Iversen 2019). In tropical forests growing on geologically old and highly weathered soils, large amounts of $\mathrm{P}$ are occluded within the soil matrix and not biologically available, so that nutrient cycling from leaf litter and organic material is essential to maintain plant growth (Walker and Syers 1976; Jordan and Herrera 1981; Sayer and Tanner 2010). In these ecosystems, the litter and organic layer are heavily intercepted by fine roots, which may build large root mats and networks on the

\section{R. J. Norby}

Department of Ecology and Evolutionary Biology,

University of Tennessee, Knoxville, TN, USA

\section{K. J. Schaap}

Soil Chemistry, Wageningen University, Wageningen, The Netherlands

\section{O. J. Valverde-Barrantes}

Florida International University, Institute of Environment, International Center of Tropical Biodiversity, Miami, FL, USA 
soil surface (Stark and Jordan 1978; John 1980; Jordan and Escalante 1980). Fine roots growing into the litter layer differ morphologically from the ones in mineral soil, with the former displaying higher specific root area and length (SRA, SRL), but a lower root density, likely adaptations to the higher concentrations of nutrients in the litter (Liu et al. 2016; Wang et al. 2016).

Fine roots in the litter layer may not only stimulate leaf litter mass loss, but are also responsible for taking up mineralized nutrients, especially $\mathrm{P}$ and cations, before they enter the soil solution (Cuevas and Medina 1988). Such 'direct nutrient cycling' prevents nutrients from being leached out of the system or from becoming adsorbed to the soil matrix (Went and Stark 1968; Herrera et al. 1978; Stark and Jordan 1978). Plant roots can stimulate both biochemical and biological mineralization processes (McGill and Cole 1981) to increase nutrient availability in their close vicinity, the rhizosphere. Plant roots do so by releasing enzymes such as phosphatases (Spohn and Kuzyakov 2013; Cabugao et al. 2017; Lugli et al. 2020), by exuding compounds such as sugars to stimulate microbial activity (e.g. 'rhizosphere priming'; Kuzyakov et al. 2000) or organic acids to liberate P and cations from soil minerals and soil organic matter (Keiluweit et al. 2015; Lambers et al. 2015). However, relatively little is known about if and how plant fine roots influence nutrient mineralization in the litter layer.

In tropical forests, litter decay and nutrient mineralization rates are generally fast due to hot and humid conditions, and are instead predominantly controlled by faunal litter fragmentation, litter stoichiometry and microbial decomposer activity (Cusack et al. 2009; Powers et al. 2009; Prescott 2010; Peguero et al. 2019). The biochemical depolymerization of complex molecules (e.g., cellulose, lignin, chitin or proteins) to smaller units available for uptake by plants and microbes is catalyzed by a range of extracellular enzymes (Sinsabaugh et al. 2002; Schimel and Bennett 2004). Extracellular enzyme activity and litter decomposition rates vary with litter type and litter chemistry and are often used to infer microbial activity and functioning (Allison and Vitousek 2004). However, some enzymes (e.g., acid phosphatases) mineralizing ester-bound phosphates from organic molecules, are released by both microbes and plant roots (Juma and Tabatabai 1988; Nannipieri et al. 2011). In tropical forests acid phosphatase activity has been shown to vary with tree species, root morphology and with soil $\mathrm{P}$ availability, confirming a direct plant control (Cabugao et al. 2017; Lugli et al. 2020). However, the potential role of fine root-derived phosphatases released directly into the leaf litter layer, where organic P substrate is potentially more abundant than in mineral soil layers, has not yet been explored.

Another strategy used by plants to increase $\mathrm{P}$ availability in the rhizosphere is to release exudates, such as sugars or organic acids (Hinsinger 2001; Jones et al. 2009), which can account for up to $40-60 \%$ of $\mathrm{C}$ assimilated via photosynthesis (Badri and Vivanco 2009). Plants can regulate the allocation of photoassimilates to roots and root exudation to adapt to changes in soil nutrient availability (Dakora and Phillips 2002), but they can also increase $\mathrm{C}$ allocation to roots and root exudates to maintain an increased nutrient demand in response to $\mathrm{eCO}_{2}$ (DeLucia et al. 1997; Phillips et al. 2011). As soil microbial communities are often C-limited, labile $\mathrm{C}$ compounds in root exudates, such as sugars, can provide a readily bioavailable energy-source, facilitating the depolymerization of more complex molecules (Dijkstra et al. 2013). However, in contrast to mineral soil, leaf litter is a C-rich substrate and soluble $\mathrm{C}$ released from the decaying plant tissues may provide sufficient substrate for heterotrophic microbes (Cotrufo et al. 2015; Soong et al. 2020). On the other hand, labile $\mathrm{C}$ inputs by fine roots could be favored over litter bound $\mathrm{C}$ as a substrate by microbes, which could reduce litter decomposition and nutrient mobilization (Barantal et al. 2012). In contrast to sugars, carboxylic or organic acids (e.g. citric acid), which have been shown to be released by plants in response to $\mathrm{P}$ deficiency, can modify $\mathrm{pH}$ and/or redox potential in the rhizosphere (Jones et al. 2004). This can change adsorption equilibrium of $\mathrm{P}$ in the mineral soil matrix (Hinsinger 2001; Lambers et al. 2015), and therefore organic acids released by fine roots could increase $\mathrm{P}$ and cation availability in the soil directly without mediation by the microbial community (Keiluweit et al. 2015).

In tropical forests growing on nutrient poor soils, fine roots heavily colonize the litter layer, still little is known about their morphological traits, their role in litter decomposition and nutrient release (Herrera et al. 1978; Stark and Jordan 1978), as well as about the mechanisms that mediate such processes. We hypothesized that fine roots stimulate leaf litter decomposition and nutrient release either i) biochemically by releasing enzymes, such as phosphatases targeting organic $\mathrm{P}$ forms, and/ or ii) by releasing labile carbon to stimulate microbial decomposers or to mobilize inorganic $\mathrm{P}$ directly. Based on a theoretical increased belowground $\mathrm{C}$ allocation 
under $\mathrm{eCO}_{2}$, we hypothesized that iii) increased inputs of labile $\mathrm{C}$ into the litter layer will either increase microbial activity or promote direct $\mathrm{P}$ mobilization. To test our hypotheses, we conducted an in-situ leaf litter decomposition experiment with native leaf litter with roots present and excluded over the course of 188 days in a tropical rainforest growing on old and weathered soils in Central Amazonia. The litterbags received, either water or two different labile $\mathrm{C}$ substrate additions (glucose and citric acid). We monitored litter fine root colonization, litter mass loss and remaining litter $\mathrm{C}$, nitrogen $(\mathrm{N}), \mathrm{P}$ and cation concentrations and aimed to partition the potential contributions of fine roots in plant biochemical and biological nutrient acquisition.

\section{Materials and methods}

Study site

The study was carried out in the experimental area of the AmazonFACE program (Lapola and Norby 2014), located in the Cuieiras Reserve about $60 \mathrm{~km}$ north of Manaus (Amazonas, Brazil), maintained by the National Institute of Amazonian Research (INPA). The study area was located on a plateau covering an area of about 5 ha, where the vegetation is composed of a dense, mature and undisturbed rainforest typical of a Central Amazonian Terra-firme forest (Pereira et al. 2019). The soil is a clay rich and highly weathered Geric Ferralsol with a low concentration of total P and rock-derived nutrients; a large proportion of $\mathrm{P}$ is bound to secondary soil minerals, such as iron and aluminum oxides (Quesada et al. 2010, 2011). The average annual rainfall is $2,400 \mathrm{~mm}$, with a low monthly precipitation $(<100 \mathrm{~mm})$ from July to September, and the average annual temperature is $26{ }^{\circ} \mathrm{C}$ (Araújo et al. 2002).

\section{Experimental design}

We conducted a leaf litter decomposition experiment starting in August 2016. The leaf litter used for the experiment was collected biweekly from eight litter traps ( $50 * 50 \mathrm{~cm}, 1 \mathrm{~m}$ above the ground) over the course of one year before the start of the decomposition experiment (August 2015 to August 2016). Leaf litter was ovendried at $65{ }^{\circ} \mathrm{C}$ for $72 \mathrm{~h}$ and stored dry. For the litter decomposition experiment, samples from all collections were pooled and homogenized, forming a mix of leaves of different species. We prepared litterbags with 2-mm and 50- $\mu \mathrm{m}$ mesh-sizes (90 per mesh size). Litterbags of 2-mm mesh size $\left(15^{*} 25 \mathrm{~cm}\right)$ were filled with $8 \mathrm{~g}$ of dry leaf litter mix and were used to monitor decomposition, allowing fine roots to colonize the material (root presence). Litterbags of $50-\mu \mathrm{m}$ mesh size $(10 * 12 \mathrm{~cm})$, filled with $6 \mathrm{~g}$ of dry leaf litter mix were used to monitor decomposition excluding fine root colonization (root exclusion). Consequently, the root exclusion bags also excluded colonization by mycorrhizal hyphae and soil macrofauna, but still allowed water and air exchange, as well as microbial colonization. We moved the root exclusion litterbags once a week to additionally eliminate any potential colonization by fine roots.

We wanted to test the influence of different labile $\mathrm{C}$ inputs during litter decomposition with and without roots present, reducing, replacing, and increasing root derived labile $\mathrm{C}$ inputs, respectively. To achieve this, we split both root presence and root exclusion litterbags to receive two different labile $\mathrm{C}$ substrates, namely glucose and citric acid, as well as water as a control. We estimated the annual litter $\mathrm{C}$ input based on data collected by Luizao and Schubart (1987) in areas of the Central Amazon. Based on this, we aimed to increase labile C inputs by $10 \%$ over 6 months, resulting in $0.31 \mathrm{mg} \mathrm{C} \mathrm{g}^{-1}$ dry litter in root presence and $0.41 \mathrm{mg}$ $\mathrm{C}^{-1}$ dry litter in root exclusion treatments added weekly as either glucose or citric acid. All other litterbags received deionized water to account for the additional water inputs. The litterbags were placed directly on the soil surface distributed in the forest in six spatially separated blocks (of an area of about $3 * 3 \mathrm{~m}$ ) at least $10 \mathrm{~m}$ apart from each other. Each block consisted of five bags of each of the six treatments: both root presence and root exclusion litterbags either with water, glucose, or citric acid addition. One bag per treatment and block was then collected after 38, 72, 101, 156 and 188 days, resulting in six replicate bags per treatment and collection time-point.

Sample collection, root colonization and litter decomposition

After each collection, litterbags were screened for colonizing roots, which were separated from the remaining litter mass. The total remaining leaf litter was weighed fresh, then cut to smaller pieces and further homogenized, and subsamples 
were prepared to determine microbial biomass and potential extracellular enzymatic activity (see detailed description below). The remaining litter was weighed again fresh and then dried at $65^{\circ} \mathrm{C}$ for $72 \mathrm{~h}$ to determine the water content and a dry weight to fresh weight ratio, which was used to calculate the total dry weight of the remaining litter. Subsamples of the dried litter were used to determine carbon and nutrient concentrations. Litter decomposition was calculated as the total litter mass remaining (\%) as follows:

Litter mass remaining $=\frac{W_{t n}}{W_{t 0}} * 100$

where $\mathrm{W}_{\mathrm{t} 0}$ is the initial dry weight of leaf litter, and $\mathrm{W}_{\mathrm{tn}}$ is the dry weight at a given collection time (tn). Litter mass loss was obtained by the difference between the initial mass (100\%) and litter remaining mass (\%) of each collection. To describe the rate of decomposition over time, litter decay rates $(\mathrm{k})$ were estimated with the commonly used first-order negative exponential decay model (Olson 1963):

$X_{t n}=X_{t 0} e^{-k t}$

where $\mathrm{Xt}_{0}$ and $\mathrm{X}_{\mathrm{tn}}$ are initial and final litter masses, respectively, and $t$ is time (days).

Root sampling and morphological parameters

Fine root biomass was determined by collecting all fine roots $<2 \mathrm{~mm}$ diameter in each litterbag. First, all roots collected per sample were scanned to determine root morphological traits. The images were obtained in high resolution at $600 \mathrm{dpi}$ and analyzed using the software WinRHIZO (WinRHIZO Regular, Regent Instruments, Canada) to determine mean root diameter, root tissue density (RTD) specific root length (SRL), specific root area (SRA; Metcalfe et al. 2007). After scanning, all roots were dried for $72 \mathrm{~h}$ at $65{ }^{\circ} \mathrm{C}$ and re-weighed. RTD was calculated as root dry mass per unit root volume $\left(\mathrm{mg} \mathrm{cm}^{-3}\right)$, SRL as the length per unit root dry mass $\left(\mathrm{cm} \mathrm{mg}^{-1}\right)$, and SRA as fine root surface area per unit dry mass $\left(\mathrm{cm}^{2} \mathrm{mg}^{-1}\right)$. Finally, we estimated the annual net change in fine root biomass in the litter layer by calculating the colonization between day 0 and 156 (where a peak in root biomass was detected).
Structural compounds and nutrient analyses of the litter samples

Since we expected fine roots to stimulate the decomposition of structural compounds and decrease nutrient concentrations in the collected remaining leaf litter, all samples were analyzed for lignin and cellulose composition, as well as for total $\mathrm{C}, \mathrm{N}, \mathrm{P}$ and cations. Dried leaf litter samples collected at day 0 , 101 and 188 of the decomposition experiment were milled to fine powder for chemical analyses. We determined structural litter compounds (i.e. lignin and cellulose) using the method described by Van Soest (1963). Total C and N were analyzed by mass spectrometry in an automatic $\mathrm{CN}$ analyzer (Vario Max CN, Elemental Analyzer, Germany). Total concentrations of phosphorus (P), potassium $(\mathrm{K})$, calcium $(\mathrm{Ca})$ and magnesium $(\mathrm{Mg})$ were analyzed after digesting samples with nitro-perchloric acid solution as described by Malavolta et al. (1989). Total P was determined colorimetrically (Murphy and Riley 1962; Olsen and Sommers 1982) and read on a UV spectrophotometer (Model 1240, Shimadzu, Kyoto, Japan). Cation concentrations ( $\mathrm{K}, \mathrm{Ca}, \mathrm{Mg}$ ) were measured by atomic absorption spectrophotometry (AAS, $1100 \mathrm{~B}$, Perkin Elmer, Ueberlingen, Germany) as described by Anderson and Ingram (1993). The proportion of remaining structural compounds or element concentrations in the litter throughout the decomposition experiment was calculated as follows by (McGroddy et al. 2004):

$R E=\frac{X_{t} * W_{t}}{X_{0} * W_{0}} * 100$

where $\mathrm{RE}$ are the remaining elements, $\mathrm{X}_{0}$ is the initial mean concentration of litter elements or structural compounds (Table 1), $\mathrm{X}_{\mathrm{t}}$ is the concentration of elements at a given collection time $(t), W_{0}$ is the initial dry weight of the litter and $\mathrm{W}_{\mathrm{t}}$ is the dry weight at a given collection time $(\mathrm{t})$.

Microbial biomass $\mathrm{C}, \mathrm{N}$ and $\mathrm{P}$

We hypothesized that excluding roots reduces, but labile $\mathrm{C}$ input stimulates microbial biomass $\mathrm{C}, \mathrm{N}$ and $\mathrm{P}$ in the leaf litter. We used the chloroform fumigation extraction method to determine microbial biomass $\mathrm{C}$, 
Table 1 Initial chemical composition of leaf litter used for the decomposition experiment

\begin{tabular}{lrl}
\hline & Average & $\pm \mathrm{SE}$ \\
\hline Total C $(\%)$ & 47.86 & \pm 0.19 \\
Total N (\%) & 1.50 & \pm 0.02 \\
Total P $\left(\mathrm{g} \mathrm{kg}^{-1}\right)$ & 0.13 & \pm 0.002 \\
C:N molar & 35.58 & \pm 1.56 \\
C:P molar & $9,621.85$ & $\pm 1,737.37$ \\
Lignin content $(\%)$ & 37.87 & \pm 2.20 \\
Cellulose content $(\%)$ & 28.06 & \pm 1.06 \\
Total K $\left(\mathrm{g} \mathrm{kg}^{-1}\right)$ & 0.90 & \pm 0.02 \\
Total Ca $\left(\mathrm{g} \mathrm{kg}^{-1}\right)$ & 4.46 & \pm 0.09 \\
Total Mg $\left(\mathrm{g} \mathrm{kg}^{-1}\right)$ & 1.60 & \pm 0.009 \\
\hline
\end{tabular}

Nutrient ratios (C:N, C:P) are molar based. Values shown are means and $\operatorname{SE}(n=6)$

$\mathrm{N}$ and $\mathrm{P}$ in aliquots of fresh litter within $48 \mathrm{~h}$ after litterbag collection (Vance and Nadkarni 1990). From each sample, $1 \mathrm{~g}$ of leaf litter was fumigated with chloroform for $24 \mathrm{~h}$. Samples were divided into two aliquots $(0.5 \mathrm{~g}$ each), one for extractions with $20 \mathrm{ml}$ of $1 \mathrm{M} \mathrm{KCl}$ to analyze organic extractable $\mathrm{C}$ and total extractable $\mathrm{N}$, and another for extractions with $20 \mathrm{ml}$ of $0.5 \mathrm{M} \mathrm{NaHCO}_{3}(\mathrm{pH} \mathrm{8.5)}$ to analyze total extractable P. In parallel, another set of samples was prepared for extraction with the same extractors without the fumigation step. Fumigated and non-fumigated $\mathrm{KCl}$ extracts were analyzed for $\mathrm{KCl}$ extractable organic $\mathrm{C}$ and total extractable $\mathrm{N}$ on a TOC/TN analyzer (TOC-V CPH E200V/TNM-1 220 V, Shimadzu, Vienna, Austria). Similarly, total extractable (labile) $\mathrm{P}$ concentrations in fumigated and non-fumigated $\mathrm{NaHCO}_{3}$ extracts were determined photometrically after persulfate digestions (Murphy and Riley 1962; Olsen and Sommers 1982) and analyzed on a UV spectrophotometer (Model 1240, Shimadzu, Kyoto, Japan). Microbial C, N and P were estimated as the difference between concentrations determined in the respective fumigated and non-fumigated extracts and expressed per unit of litter dry mass, without correction for extraction efficiency (Jenkinson et al. 2004).

Potential extracellular enzyme activity

We expected that fine root exclusion decreases PHOS activity stronger than the activity of other enzymes exuded only by microbial decomposers. We therefore measured the activity of four different extracellular enzymes: acid phosphatases (PHOS), released by plant roots and microbes, as well as of cellobiosidase (CB), B-glucosidase (BG), and $\mathrm{N}$-acetylglucosaminidase (NAG) all released by microbes. Within $48 \mathrm{~h}$ after litterbag collections a subsample of fresh litter per collected litterbag was used to determine potential extracellular enzyme activity rates. The assays were performed using 4-methylumbelliferyl (4-MUF) marked substrates. We used 4-MUF-phosphate as substrate for PHOS, 4-MUF-cellobioside to analyze CB, 4-MUF- $\beta$-D-glucopyranoside for BG, and 4-MUF-N-acetyl- $\beta$-D-glucosaminide for the exochitinase NAG (Marx et al. 2001; Saiya-Cork et al. 2002; DeForest 2009). Briefly, a slurry with $0.5 \mathrm{~g}$ of litter

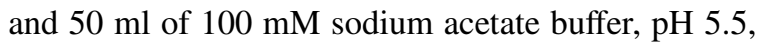
was homogenized by vigorous stirring using a vortex for $1 \mathrm{~min}$. Per sample, slurry was pipetted in triplicates into black microplates and incubated with the respective substrates in the dark at room temperature $\left(25^{\circ} \mathrm{C}\right)$ for $40 \mathrm{~min}$; in addition, we included substrate and quenching blanks in triplicates per plate on all microplates (German et al. 2011). Then fluorescence was measured on a microplate analyzer (TECAN i-control 200Pro, Groedig, Austria) at $365 \mathrm{~nm}$ excitation and $450 \mathrm{~nm}$ emission. Potential extracellular enzyme rates were calculated according to German et al. (2011) and enzymatic activity is expressed in nmol g ${ }^{-1}$ dry leaf $\mathrm{h}^{-1}$.

\section{Statistical analysis}

We tested the effects of root presence/exclusion and labile $\mathrm{C}$ additions on leaf litter decomposition, nutrient dynamics, microbial biomass, and extracellular activity with linear mixed models (LMMs) using the package lme4 by the lmer function (Bates et al. 2015) in R (R Core Team 2020). First, we tested the effect of fine root presence/exclusion (considering only the samples that received no labile $\mathrm{C}$ additions). Second, we tested the effects of labile $\mathrm{C}$ additions and potential interactions with fine root presence/exclusion using the entire data set, with labile $\mathrm{C}$ addition and root presence/exclusion as fixed factors. In all models 'time' and 'blocks', were considered as random factors to account for temporal and spatial heterogeneity. In both analyses' groups (no labile C addition and entire dataset), we used Akaike's information criterion (AIC) to determine the best model 
(least significant fixed effects and interaction between them), retaining the one with the lowest AIC value. The residuals of all variables were checked for normality and homogeneity of variance. Post-hoc tests accounting for multiple comparisons between treatments were conducted using Tukey's test available in emmeans package (Lenth et al. 2020).

\section{Results}

Fine root colonization of leaf litter

In root exclusion litterbags no roots were detectable. In litterbags with fine root access fine root colonization was detectable only at the second collection (after 72 days) of the litter decomposition experiment. After 72 days, fine root biomass in controls receiving water additions increased to $1.74 \mathrm{~g} \mathrm{~m}^{-2}$ $( \pm 0.84, \mathrm{SE})$, reaching a peak of $6.81 \mathrm{~g} \mathrm{~m}^{-2}( \pm 1.37$, SE) after 156 days (Fig. 1), which was estimated as a net increase in fine root biomass of $15.9 \mathrm{~g} \mathrm{~m}^{-2} \mathrm{yr}^{-1}$. From day 156 to 188 , there was a $54.5 \%$ reduction of

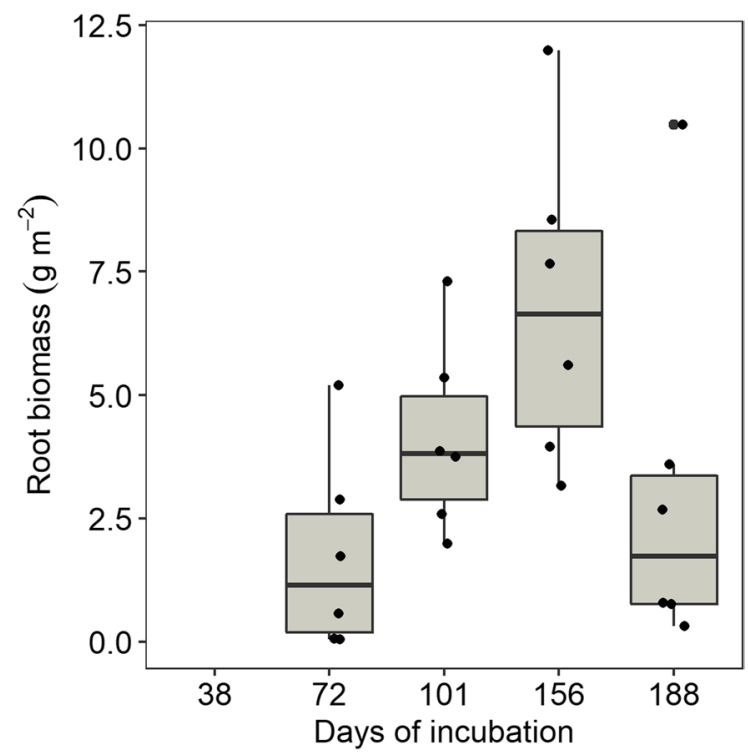

Fig. 1 Fine root biomass over the course of the leaf litter decomposition experiment for samples with root presence and no labile $\mathrm{C}$ additions (control). No root growth was detected by day 38 of the experiment. Box plot midlines are medians, box edges are first and third quartiles, whiskers indicate minimums and maximums, and dots indicate individual measurements $(n=6)$ fine root biomass to $3.10 \mathrm{~g} \mathrm{~m}^{-2}( \pm 1.60$, SE; Fig. 1). Labile $\mathrm{C}$ additions had no significant effect on fine root biomass during the experiment (Table S1). The average diameter of the fine roots collected per litterbag ranged between 0.17 and $1.01 \mathrm{~mm}$, and RTD from 84 to $925 \mathrm{mg} \mathrm{cm}^{-3}$. SRL ranged from 0.75 to $13.22 \mathrm{~cm} \mathrm{mg}^{-1}$, and SRA from 0.14 to $1.41 \mathrm{~cm}^{2} \mathrm{mg}^{-1}$ (Fig. S1). Fine root morphology did not vary significantly over time and was not affected by labile C additions (Table S1).

The effect of fine roots on litter decomposition dynamics

The presence/exclusion of fine roots had no significant effect on the remaining leaf litter mass over the course of our experiment (Table S1, Fig. 2a), with litter mass decay constants $(k)$ of 1.01 and 0.94 year $^{-1}$ with roots present and excluded, respectively. The presence of fine roots did, however, significantly reduce structural compounds, in particular the lignin fraction in the remaining litter $\left(F_{1: 16}=8.04, P=0.01\right.$; Fig S2a).

Similar to litter mass loss, root presence/exclusion did not change the loss of $\mathrm{C}$ and $\mathrm{N}$ from litter (Table S1; Fig. 3a-b, for $\mathrm{C}$ and $\mathrm{N}$, respectively). In contrast, fine root presence significantly stimulated the loss of $\mathrm{P}$ and cations from litter. Total remaining $\mathrm{P}$ in the litter after 188 days was significantly lower with root presence than when roots were excluded (64.3\% vs. $98.4 \%$, respectively) $\left(F_{1: 29} 11.21, P=0.002\right)$. Similarly, at the end of the experiment fine root presence reduced remaining $\mathrm{K}\left(F_{1: 52}=10.67, P=0.001\right), \mathrm{Ca}$ $\left(F_{1: 29}=13.34, \quad P=0.001\right)$, and $\mathrm{Mg} \quad\left(F_{1: 48}=23.64\right.$, $P=0.001$ ), which were $8.9,23.4$, and $20.0 \%$, respectively, lower compared to litter with root exclusion (Fig. 3d-f).

Labile $\mathrm{C}$ addition effects on litter decomposition dynamic

The effect of glucose and citric acid addition on the remaining leaf litter mass did not differ between root presence/exclusion, but it changed with the $\mathrm{C}$ compound added $\left(F_{2: 146}=3.03, P=0.05\right)$; compared to controls and glucose treatments, citric acid additions significantly reduced litter mass loss (Fig. 2b). In contrast, labile $\mathrm{C}$ additions influenced the release of $\mathrm{P}$ $\left(F_{2: 163}=4.84, P=0.01\right)$ and $\mathrm{K}\left(F_{2: 142}=3.50, P=0.03\right)$ 


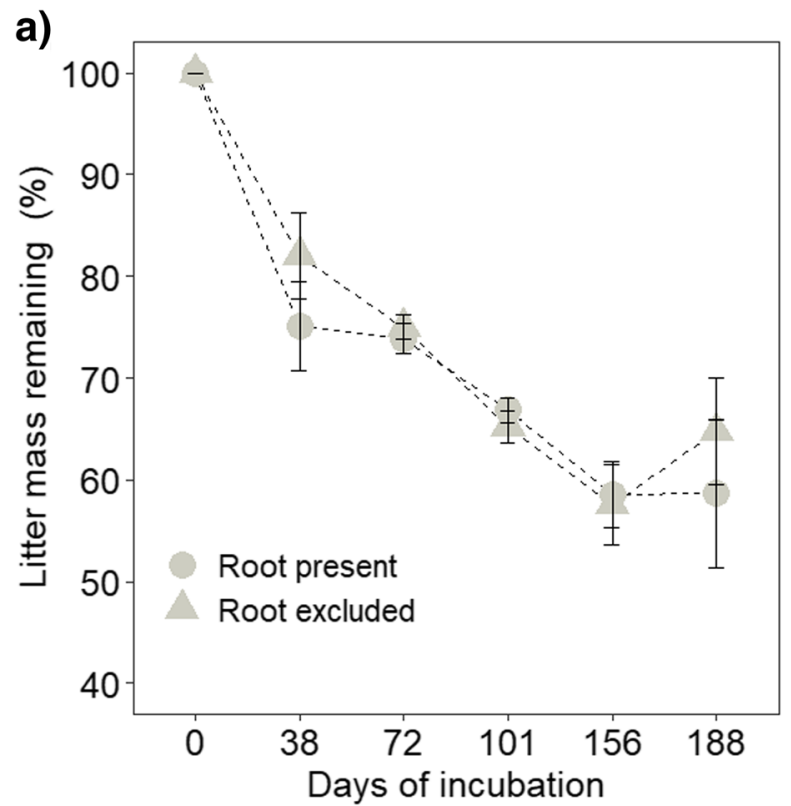

Fig. 2 Litter mass remaining (in \% of initial litter mass) over the course of the decomposition experiment: a) no significant effect of fine roots present (circles) or fine root exclusion (triangles) on litter mass remaining (water-controls, $n=6$ ) and $\mathbf{b}$ )

from the litter depending on root presence/exclusion (root presence*labile $\mathrm{C}$ addition). With fine roots present, glucose additions stimulated $\mathrm{P}$ and $\mathrm{K}$ release compared to root exclusion (Fig. 4a, b), while citric acid additions reduced the release of $\mathrm{K}$ compared to glucose additions and water controls (Fig. 4d).

Potential extracellular enzyme activity and microbial biomass during litter decomposition

We found that activity rates of all enzymes considered to be released by microorganisms, such as $\mathrm{CB}$ and BG (involved in cellulose degradation), and NAG (catalyzing the degradation of glucosamine), showed a high temporal variation with a sharp increase in the first 38 days, followed by a constant decrease over the course of the experiment. However, $\mathrm{CB}, \mathrm{BG}$ and NAG were not affected by root presence/exclusion, nor by labile $\mathrm{C}$ additions (Table S1; Fig S4). In contrast, on average across all time points PHOS was significantly increased by $43.2 \%$ when roots were present compared to root exclusions $\left(F_{1: 29}=11.43, P=0.002\right.$; Fig. 5a). Glucose additions increased PHOS activity only when roots were excluded, but not when roots

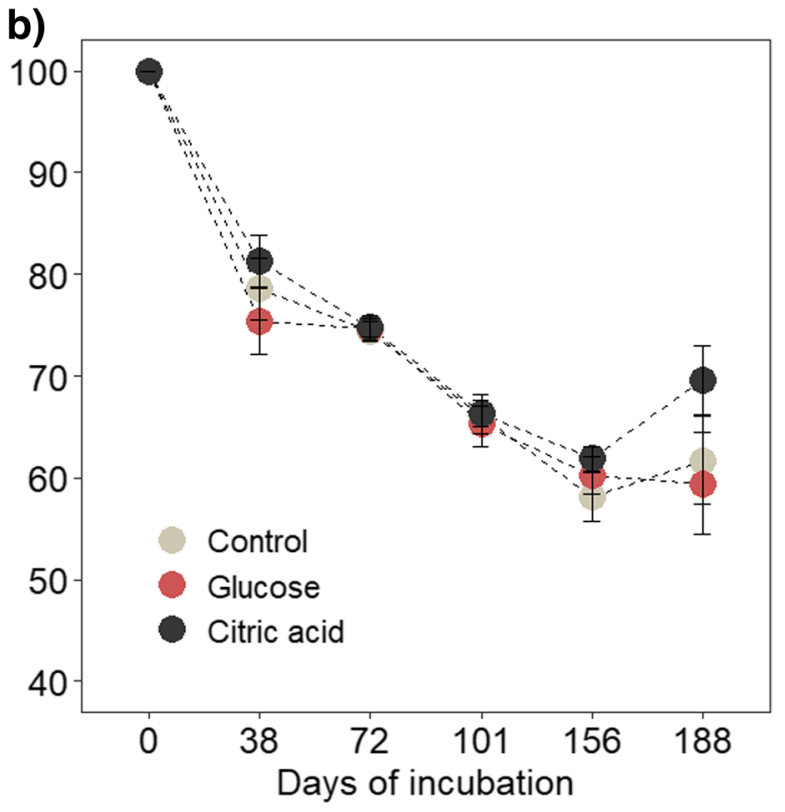

no significant influence of water (grey circle), glucose (red circle) or citric acid (blue circle) additions on the remaining litter mass (combining root presence and exclusion treatments, $n=12$; error bars show standard errors of means)

were present. In contrast, citric acid addition consistently resulted in lower PHOS activity compared to samples receiving glucose additions, regardless of fine root presence/exclusion $\left(F_{2: 141}=5.14, P=0.006\right.$; Fig. 5b).

Microbial biomass $\mathrm{C}, \mathrm{N}$ and $\mathrm{P}$ varied strongly during the litter decomposition experiment, reaching a maximum at 101 days (Fig S5). Microbial biomass C was neither affected by fine roots presence/exclusion, nor by labile $\mathrm{C}$ additions. In contrast, microbial $\mathrm{N}$ and $\mathrm{P}$ were lower in litter bags with citric acid additions compared to controls, whereas glucose addition had no effect $\left(F_{2: 76}=3.04, P=0.05\right.$ and $F_{2: 124}=3.85$, $P=0.02$ respectively; Fig S5).

\section{Discussion}

In tropical forests fine roots often form large mats within the litter layer, but little is known about their characteristics, as well as the mechanisms they apply in nutrient foraging and their interactions with microbial decomposers. Contrary to our first hypothesis that roots stimulate litter mass loss, we 
a)
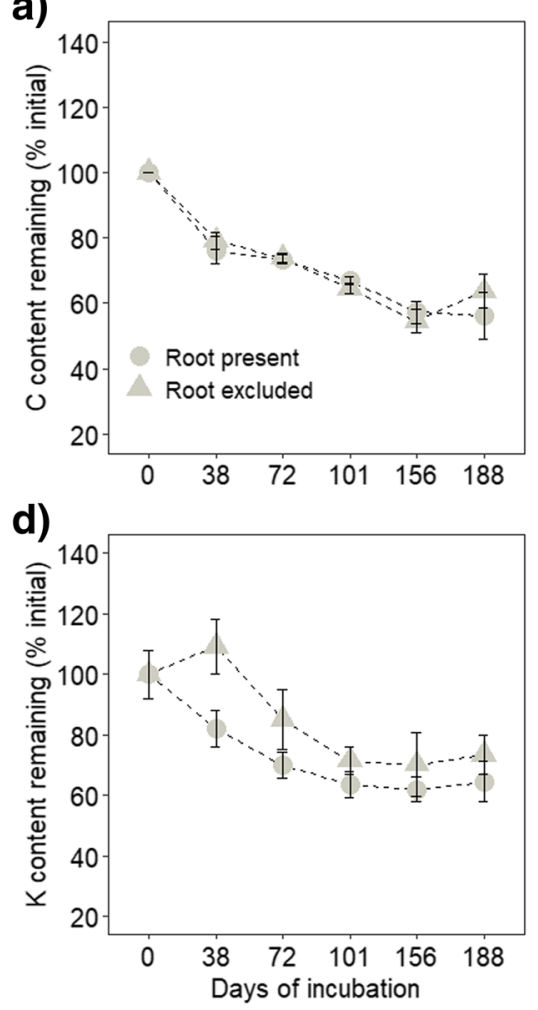

b)

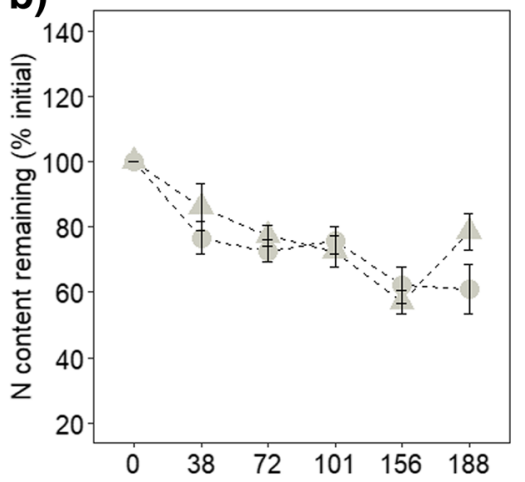

e)

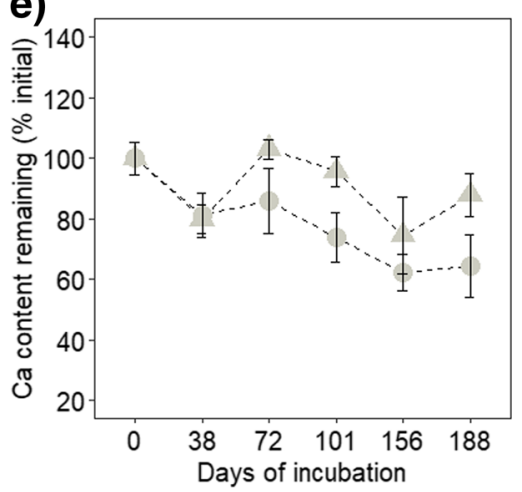

c)
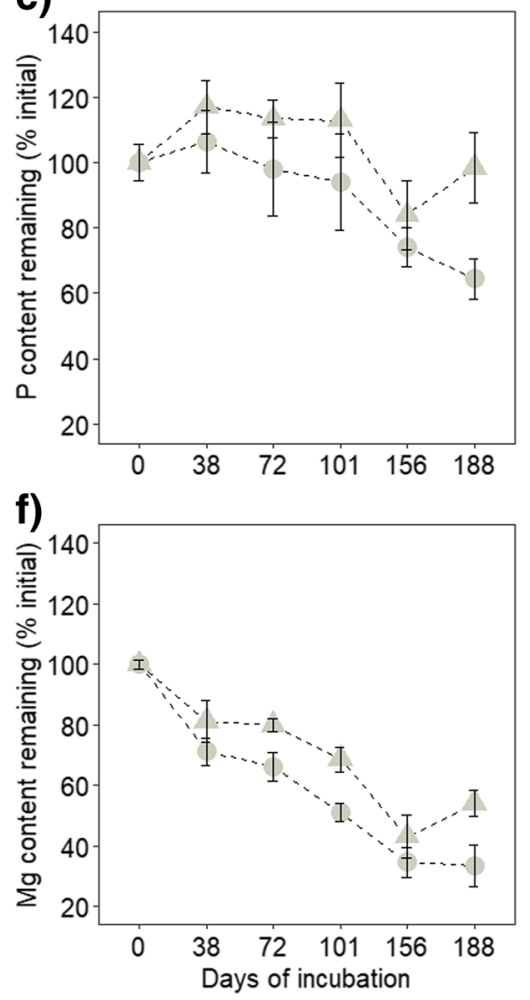

Fig. 3 Element dynamics in remaining leaf litter over the course of the decomposition experiment with fine roots present and excluded of controls only. The figures show litter mass loss corrected remaining nutrient content in $\%$ of the samples of a) total carbon, b) total nitrogen, c) total phosphorus, d) potassium e) calcium, f) and magnesium; (error bars show standard errors of means for $n=6$ )

Fine roots do not accelerate litter mass loss, but stimulate nutrient mobilization

Fine roots accessing nutrients directly in the surface litter layer is likely one of the most important strategies of "direct nutrient cycling" in tropical forests (Went and Stark 1968; Stark and Jordan 1978; Jordan and Escalante 1980). Indeed, our study site was characterized by high net fine root production in the litter layer (15.9 $\mathrm{g} \mathrm{m}^{-2} \mathrm{yr}^{-1}$ ), which was higher than in a tropical forest in Panama $\left(5.7 \mathrm{~g} \mathrm{~m}^{-2} \mathrm{yr}^{-1}\right.$; Sayer et al. 2006) and in temperate forests $\left(2.6 \mathrm{~g} \mathrm{~m}^{-2} \mathrm{yr}^{-1}\right.$; Liu et al. 2016), corroborating their important role for nutrient recycling in this ecosystem. Morphological traits of fine roots colonizing the litter layer in our experiment were comparable to those in the 
Fig. 4 The influence of labile $\mathrm{C}$ additions on $\mathbf{a})$ remaining mass of initial phosphorus (\%) and b) remaining mass of initial potassium (\%) in leaf litter during 188 days of decomposition with fine roots present and excluded; (error bars show standard errors of means for $n=6$ )

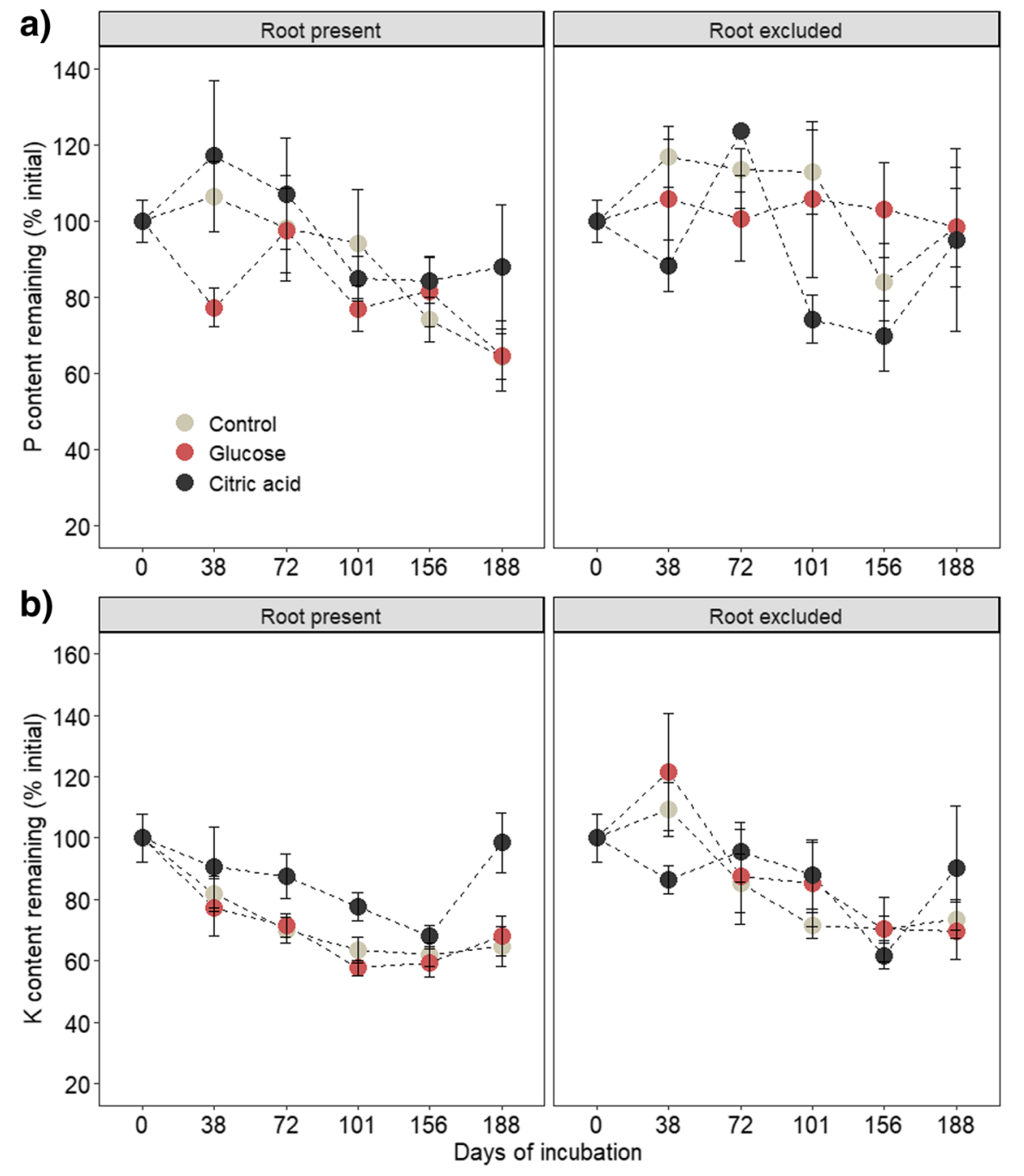

upper mineral soil layers of a nearby tropical forest site (Lugli et al. 2020). However, both SRL and RTD in the litter were slightly higher than in mineral soil (Lugli et al. 2020), indicating that roots in the litter layer are thinner but denser, possibly as an adaptation to harsh environmental conditions in the upper litter layer (Eissenstat and Yanai 1997; Laliberté et al. 2015; Ushio et al. 2015).

The litter decay constant $k$ in our study was comparable to those found in other tropical sites (Hättenschwiler et al. 2011). However, in contrast to our hypothesis and earlier observations by Cuevas and Medina (1988), in our experiment, fine roots did not affect total litter mass, nor $\mathrm{C}$ and $\mathrm{N}$ loss, but reduced the lignin fraction in the remaining litter, which may have led to an accelerated mass loss in later stages of decomposition. Excluding fine roots may have excluded soil meso- and likely some soil microfauna (Powers et al. 2009; Peguero et al. 2019), however, we did not find a significant impact on litter mass loss. Moreover, the lack of differences in mass loss rates suggests that the size of the litterbags did not influence the results. Nevertheless, we detected a significantly higher loss of $\mathrm{P}, \mathrm{K}, \mathrm{Ca}$, and $\mathrm{Mg}$ from leaf litter when fine roots were present than when they were excluded (Fig. 3c-f). This supports the hypothesis that fine roots stimulate nutrient mobilization from the litter (Cuevas and Medina 1988) and corroborates findings by Luizão et al. (2007) in an Amazonian tropical forest, that fine roots increase the release of cations ( $\mathrm{Ca}, \mathrm{Mg}, \mathrm{Mn}$, and $\mathrm{Zn}$ ) without inducing changes in litter decomposition. Such differential effects of 


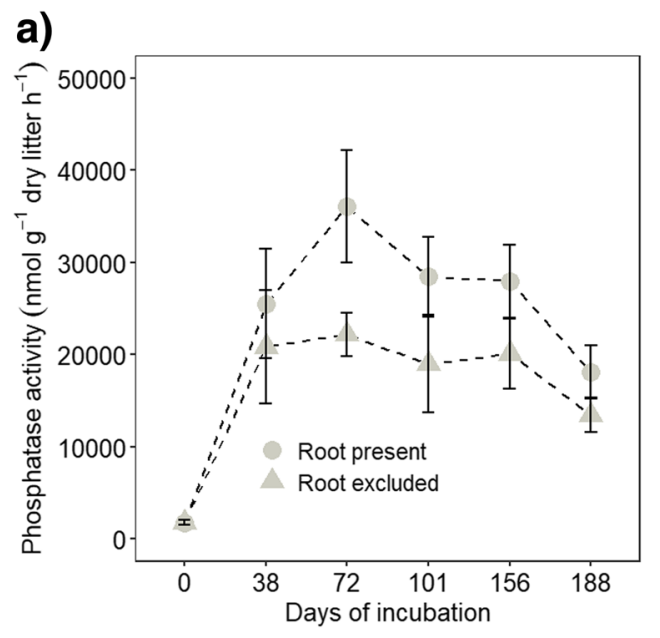

Fig. 5 Potential activity of acid phosphatase (PHOS) over the course of the leaf litter decomposition experiment a) Effect of fine root presence or exclusion only of samples without labile

fine root presence on $\mathrm{C}$ and nutrient mineralization rates may indicate different controls over biochemical (via enzymes) and biological mineralization (via microbes) during decomposition as suggested by McGill and Cole (1981).

Biochemical and biological mineralization processes during litter decomposition

In the litter layer organic matter bound $\mathrm{C}, \mathrm{N}$ and $\mathrm{P}$ bound in organic matter are the main (energy) source for heterotrophic microorganisms. In particular during the early phase of litter decomposition, the predominant release of soluble fractions triggers a sequence of microbial succession starting with opportunists specialized in quickly accessing those labile resources, followed within weeks and months by more specialized decomposers able to break down the more complex cellulose and lignin fractions (Moorhead and Sinsabaugh 2006; DeAngelis et al. 2013; Cotrufo et al. 2015). In accordance, we found that independent of the presence of fine roots, $30 \%$ of the litter mass was already lost in the initial 101 days of the experiment (in particular soluble and cellulose compounds, Fig. S2). Simultaneously, microbial $\mathrm{CB}$ and $\mathrm{BG}$ rates peaked, which suggests they were released as a response to increased cellulose and polysaccharide substrate availability, rather than to high microbial C demand (Nannipieri et al. 2012). Litter
$\mathrm{C}$ additions (controls) and $\mathbf{b})$ Effect of labile $\mathrm{C}$ additions effect with root present and excluded; (error bars show standard errors of means for $n=6$ )

colonization by microbes (including potentially by mycorrhizal hyphae) seemed to have happened fast and independently of fine root colonization. During litter decomposition microbes can become temporarily limited by $\mathrm{N}$ (or $\mathrm{P}$ ), especially when litter $\mathrm{C}: \mathrm{N}$ ratios are above 40 (Parton et al. 2007); in our experiment, litter C:N was between 34.0 and 37.1, therefore we would instead expect sufficient $\mathrm{N}$ available for enzyme production or a net release of $\mathrm{N}$ during decomposition, but no microbial $\mathrm{N}$ limitation.

Phosphorus, in contrast, can be mineralized biochemically independently by phosphatases catalyzing the hydrolysis of $\mathrm{PO}_{4}^{-}$without $\mathrm{CO}_{2}$ production (McGill and Cole 1981; Dijkstra et al. 2013). Our findings suggest that when roots were colonizing leaf litter, both PHOS activity rates and P losses were higher, which confirms our hypothesis that plants invest in enzymes to mobilize P from litter, and do not only rely on microbial enzymatic PHOS activity. Although similar patterns have previously been observed in mineral soils (Spohn and Kuzyakov 2013; Cabugao et al. 2020), we here identified for the first time root-derived PHOS activity as an active mechanism also in the litter layer in a tropical forest. However, as Spohn and Kuzyakov (2013) reported, not only plant but also microbial PHOS activity can be higher in the rhizosphere and, we may have overestimated the plant-derived PHOS contribution, as by excluding roots we also excluded 
rhizosphere microbial communities. In our experiment the microbial decomposer community seemed to be strongly limited by $\mathrm{P}$ as the initial leaf litter $\mathrm{C}: \mathrm{P}$ ratio was 9621 , and values $>1800$ have been found to strongly reduce microbial $\mathrm{P}$ mobilization (Mooshammer et al. 2012). Indeed, we observed high $\mathrm{P}$ immobilization in the colonizing microbial biomass, regardless of root presence or absence (Fig. S5).

The role of fine roots and microbial communities in releasing cations from litter has hardly been addressed before. As with $\mathrm{P}$, the variation in cations in the Amazon basin follows a pedogenic gradient, with lower concentrations of available cations in more weathered soils (Quesada et al. 2010, 2011). In our study, we found that not only $P$, but also $\mathrm{K}, \mathrm{Ca}$ and $\mathrm{Mg}$ mobilization from litter was significantly higher when roots were present. This further corroborates findings from a nutrient manipulation experiment in the Central Amazon (Lugli et al. 2021), which suggests that cations might be as important for plant metabolism as P. Another mechanism for intercepting $\mathrm{P}$ and other mineral nutrients directly from the litter layer in tropical forests is the symbiotic association between fine roots and arbuscular mycorrhizal fungi (Herrera et al. 1978; Hättenschwiler et al. 2011; Lu and Hedin 2019). Although arbuscular mycorrhizal fungi may be less efficient in organic matter degradation compared to ectomycorrhizal fungi (Hodge et al. 2001), they still increase the absorptive surface area of fine roots (Smith and Read 2008; Bunn et al. 2019), and they can be highly efficient in the acquisition not only of $\mathrm{P}$, but also of other elements, such as $\mathrm{Ca}, \mathrm{Mg}, \mathrm{K}$ and Sulphur (Siqueira et al. 1998; Zangaro et al. 2003). Although in our study we did not evaluate fine root colonization by mycorrhizal fungi or hyphal biomass in the litter layer, they still may have contributed to the faster decrease of $\mathrm{P}$ and cations from litter.

In summary, our results confirm that the mobilization of $\mathrm{P}$ and cations from litter occurs independently from $\mathrm{C}$ and $\mathrm{N}$ mineralization. Moreover, phosphatases released by fine roots need to be considered as mechanisms for $\mathrm{P}$ mobilization in the leaf litter layer in tropical forests. Mechanisms for direct cation mobilization in the litter layer, and the potential contribution of mycorrhizal fungi, need further investigation.
Labile $\mathrm{C}$ additions do not stimulate litter mass loss, but change mineral nutrient dynamics

Since $\mathrm{eCO}_{2}$ and climate change can induce changes in the quantity and quality of plant belowground $\mathrm{C}$ allocation and root exudation (Iversen et al. 2008; Phillips et al. 2011; Jiang 2020), we aimed to investigate the influence of different common primary compounds in root exudates known to trigger differential responses in the rhizosphere. In soils, where $\mathrm{C}$ can be a scarce resource, low molecular weight $\mathrm{C}$ exudates by roots can stimulate the decomposition of more stable soil organic matter ('rhizosphere priming'; Kuzyakov et al. 2000). In litter however, our results confirmed that independently of root presence/exclusion, the addition of glucose, a simple sugar, did not change litter mass loss, or the mineralization of $\mathrm{C}$ or $\mathrm{N}$, suggesting that microbial decomposers already have access to sufficient resources (Soong et al. 2020). In contrast, glucose additions further increased $\mathrm{P}$ release from leaf litter when fine roots were present without increasing microbial biomass or PHOS activity rates (Figs. 4 and 5). This suggests that glucose may have stimulated microbial biomass turnover, without increasing net growth or $\mathrm{P}$ immobilization, maybe due to a co-induced limitation by $\mathrm{N}$ (Barantal et al. 2012), but nevertheless this may have indirectly aided plant P acquisition (Spohn and Kuzyakov 2013). In contrast, when roots (and thereby labile $\mathrm{C}$ inputs by roots) were excluded, $\mathrm{P}$ release from litter was lower than with roots present, and glucose additions did not significantly affect $\mathrm{P}$ mobilization, but instead increased microbial PHOS activity rates. On the one hand, excluding roots may have reduced the competition between roots and microbes not only for $\mathrm{P}$, but also for $\mathrm{N}$, which could instead have been used by microbes to invest in PHOS production. On the other hand, this indicates that even in C-rich litter microbes seem to rely on labile plant $\mathrm{C}$ inputs (Barantal et al. 2012) and glucose additions may have supplemented root-derived $\mathrm{C}$ inputs for microbes providing, energy to mine for $\mathrm{P}$ to maintain and satisfy the microbial $\mathrm{P}$ demand (Dijkstra et al. 2013; Spohn and Kuzyakov 2013).

In contrast, citric acid additions tended instead to reduce litter mass loss compared to controls and glucose additions (Fig. 2b, Table S1) and reduced the microbial $\mathrm{N}$ and $\mathrm{P}$, increased microbial $\mathrm{C}: \mathrm{N}$ and $\mathrm{C}: \mathrm{P}$ ratios, and decreased NAG activity compared to 
controls (Fig. S5, Table S1). The apparent adverse effects of citric acid could be related to a change in $\mathrm{pH}$ affecting the microbial community (Jones et al. 2004), possibly selecting for fungi rather than bacteria, indicated by changes in the microbial $\mathrm{C}: \mathrm{N}$ and C:P ratios (Mouginot et al. 2014). Citric acid additions reduced the release of $\mathrm{K}$ from litter compared to glucose additions and controls only when roots were present. Exudation of organic acids into the rhizosphere has been identified as an important mechanism to increase the release of soil organic $\mathrm{C}$ from mineral complexes (Keiluweit et al. 2015) and enhance phosphate availability in soil solution (Oburger et al. 2011), but it can also form complexes with mineral cations (Welch et al. 2002); however, the influence of organic acids on the release of $\mathrm{K}$ from litter is still not clear.

In summary, this lack of positive responses to increased labile $\mathrm{C}$ inputs to leaf litter in the form of glucose additions when fine roots are present suggests that microbial decomposers may have sufficient access to $\mathrm{C}$ during initial stages of litter decomposition, when most soluble $\mathrm{C}$ compounds are released (Soong et al. 2020), and increased growth or activity could be limited by $\mathrm{N}$ or other nutrients. Nevertheless, the microbial community response and the subsequent litter decomposition and nutrient mineralization dynamics will depend directly on which $\mathrm{C}$ compounds are being exuded by roots, either stimulating microbial activity or likely by inducing microbial community shifts.

\section{Conclusions}

Our study gives observational evidence that fine root proliferation in the litter layer is an important and efficient mechanism by plants to intercept and acquire essential nutrients such as $\mathrm{P}, \mathrm{K}, \mathrm{Ca}$ and $\mathrm{Mg}$. The fact that plant roots directly stimulate biochemical (enzymatic) $\mathrm{P}$ mobilization in the litter layer could - under future $\mathrm{eCO}_{2}$ scenarios - increase the turnover and recycling of $\mathrm{P}$ in the litter layer. While this can be a competitive advantage for plants, this could reduce the $P$ returned to soil and could reduce soil microbial growth and biomass production. However, our experiment also showed that labile $\mathrm{C}$ inputs did not stimulate litter mass loss rates, but rather PHOS activity. Hence, if plants increase the allocation of $\mathrm{C}$ towards exudation under
$\mathrm{eCO}_{2}$ scenarios, this could accelerate litter $\mathrm{P}$ cycling to potentially support plant growth, but not lead to higher $\mathrm{C}$ loss from litter as heterotrophic respiration.

Acknowledgements We thank Erison Gomes and the Thematic Laboratory for Soils and Plants (Laboratório Temático de Solos e Plantas-LTSP) at INPA, Manaus, for helping with the nutrient analyses, as well as Luciano Castilho for the logistical support and leaf litter collection. We also thank the LBA Program and its staff which granted us field and operational support at the ZF-2 LBA base, as well as the Division of Terrestrial Ecosystem Research at University of Vienna. The authors would like to thank Flavia Santana for helpful suggestions and comments on previous versions of the manuscript, as well as Dr. Emma J. Sayer and two anonymous reviewers for their constructive comments. In memory of Geraldo Pires da Silva.

Authors' contributions NPM, LF and CAQ designed the study, NPM conducted and maintained the litter decomposition experiment and analyzed the collected samples with help from $\mathrm{KF}, \mathrm{LF}, \mathrm{AG}, \mathrm{KS}$ and OJVB. KMA, FBB and FH provided statistical advice. NPM, LF, and KF wrote the manuscript with significant contributions of all authors. All authors approve the final version of the manuscript.

Funding Open access funding provided by University of Vienna. The AmazonFACE program was funded by the Inter-American Development Bank through a technical cooperation agreement with the Brazilian Ministry of Science, Technology, Innovation and Communications (Grant BR-T1284), and by Brazil's Coordination for the Improvement of Higher Education Personnel (CAPES) Grants 23038.007722/2014-77 and 88881.154644/201701, as well as by the Amazonas Research Foundation (FAPEAM) Grant 2649/2014. NPM and KS received grants from CAPES. LF was supported by the European Research Council Synergy grant \#610028 Imbalance-P and by the European Union's Horizon 2020 research and innovation program under the Marie Sklodovska-Curie grant agreement No 847693 (REWIRE). IPH and KMA would like to acknowledge UK Natural Environment Research Council grant NE/L007223/1. KF acknowledges funding by the DFG Grant RA 2060/5-1. LFL would like to acknowledge CAPES for support (88887.360170/2019-00). DML was supported by a FAPESP grant (2015/02537-7).

Code availability Not applicable.

\section{Declarations}

Conflicts of interest The authors declare no conflict of interest.

Data accessibility Data is available under https://doi.org/10. 25365/phaidra.300.

Open Access This article is licensed under a Creative Commons Attribution 4.0 International License, which permits use, sharing, adaptation, distribution and reproduction in any 
medium or format, as long as you give appropriate credit to the original author(s) and the source, provide a link to the Creative Commons licence, and indicate if changes were made. The images or other third party material in this article are included in the article's Creative Commons licence, unless indicated otherwise in a credit line to the material. If material is not included in the article's Creative Commons licence and your intended use is not permitted by statutory regulation or exceeds the permitted use, you will need to obtain permission directly from the copyright holder. To view a copy of this licence, visit http://creativecommons.org/licenses/by/4.0/.

\section{References}

Allison SD, Vitousek PM (2004) Extracellular enzyme activities and carbon chemistry as drivers of. Biotropica 36:285-296. https://doi.org/10.1111/j.1744-7429.2004.tb00321.x

Anderson JM, Ingram JSI (1993) Tropical soil biology and fertility: a handbook of methods, 2nd edn. CAB International, Wallingford

Araújo AC, Nobre AD, Kruijt B et al (2002) Comparative measurements of carbon dioxide fluxes from two nearby towers in a central Amazonian rainforest: The Manaus LBA site. J Geophys Res 107:1-20. https://doi.org/10. 1029/2001JD000676

Badri DV, Vivanco JM (2009) Regulation and function of root exudates. Plant Cell Environ 32:666-681. https://doi.org/ 10.1111/j.1365-3040.2009.01926.x

Barantal S, Schimann H, Fromin N, Hättenschwiler S (2012) Nutrient and carbon limitation on decomposition in an Amazonian Moist Forest. Ecosystems 15:1039-1052. https://doi.org/10.1007/s10021-012-9564-9Ecosystems

Bates D, Mächler M, Bolker B, Walker S (2015) Fitting linear mixed-effects models using lme4. J Statiscal Softw 67:148. https://doi.org/10.18637/jss.v067.i01

Bunn RA, Simpson DT, Bullington LS et al (2019) Revisiting the 'direct mineral cycling' hypothesis: arbuscular mycorrhizal fungi colonize leaf litter, but why? ISME J 13:18911898. https://doi.org/10.1038/s41396-019-0403-2

Cabugao KG, Timm CM, Carrell AA et al (2017) Root and rhizosphere bacterial phosphatase activity varies with tree species and soil phosphorus availability in Puerto Rico Tropical Forest. Front Plant Sci 8:1-14. https://doi.org/10. 3389/fpls.2017.01834

Cabugao KG, Yaffar D, Stenson N et al (2020) Bringing function to structure : Root - soil interactions shaping phosphatase activity throughout a soil profile in Puerto Rico. 1-15. https://doi.org/10.1002/ece3.7036

Cernusak LA, Winter K, Dalling JW et al (2013) Tropical forest responses to increasing atmospheric $\mathrm{CO} 2$ : current knowledge and opportunities for future research. Funct Plant Biol 40:531-551. https://doi.org/10.1071/FP12309

Cotrufo MF, Soong JL, Horton AJ et al (2015) Formation of soil organic matter via biochemical and physical pathways of litter mass loss. Nat Geosci 8:776-779. https://doi.org/ $10.1038 /$ ngeo 2520

Cuevas E, Medina E (1988) Nutrient dynamics within amazonian forests - II. Fine root growth, nutrient availability and leaf litter decomposition. Oecologia 76:222-235. https:// doi.org/10.1007/BF00379956
Cusack DF, Chou WW, Yang WH et al (2009) Controls on long-term root and leaf litter decomposition in neotropical forests. Glob Chang Biol 15:1339-1355. https://doi.org/ 10.1111/j.1365-2486.2008.01781.x

Dakora FD, Phillips DA (2002) Root exudates as mediators of mineral acquisition in low-nutrient environments LegumeRhizobium Symbiosis View project Root exudates as mediators of mineral acquisition in low-nutrient environments. Plant Soil 245:35-47. https://doi.org/10.1023/A: 1020809400075

DeAngelis KM, Chivian D, Fortney JL et al (2013) Changes in microbial dynamics during long-term decomposition in tropical forests. Soil Biol Biochem 66:60-68. https://doi. org/10.1016/j.soilbio.2013.06.010

DeForest JL (2009) The influence of time, storage temperature, and substrate age on potential soil enzyme activity in acidic forest soils using MUB-linked substrates and 1-DOPA. Soil Biol Biochem 41:1180-1186. https://doi. org/10.1016/j.soilbio.2009.02.029

DeLucia EH, Callaway RM, Thomas EM, Schlesinger WH (1997) Mechanisms of phosphorus acquisition for ponderosa pine seedlings under high $\mathrm{CO} 2$ and temperature. Ann Bot. https://doi.org/10.1006/anbo.1996.0320

Dijkstra FA, Carrillo Y, Pendall E, Morgan JA (2013) Rhizosphere priming: a nutrient perspective. Front Microbiol 4:216. https://doi.org/10.3389/fmicb.2013.00216

Du E, Terrer C, Pellegrini AFA et al (2020) Global patterns of terrestrial nitrogen and phosphorus limitation. Nat Geosci 13:221-226. https://doi.org/10.1038/s41561-019-0530-4

Eissenstat DM, Yanai RD (1997) The ecology of root lifespan. Adv Ecol Res 27:1-60. https://doi.org/10.1016/S00652504(08)60005-7

Fleischer K, Rammig A, De Kauwe MG et al (2019) Amazon forest response to $\mathrm{CO} 2$ fertilization dependent on plant phosphorus acquisition. Nat Geosci 12:736-741. https:// doi.org/10.1038/s41561-019-0404-9

German DP, Weintraub MN, Grandy AS et al (2011) Optimization of hydrolytic and oxidative enzyme methods for ecosystem studies. Soil Biol Biochem 43:1387-1397. https:// doi.org/10.1016/j.soilbio.2011.03.017

Hättenschwiler S, Coq S, Barantal S, Handa IT (2011) Leaf traits and decomposition in tropical rainforests: Revisiting some commonly held views and towards a new hypothesis. New Phytol 189:950-965. https://doi.org/10.1111/j. 1469-8137.2010.03483.X

Herrera R, Merida T, Stark N, Jordan CF (1978) Direct phosphorus transfer from leaf litter to roots. Naturwissenschaften 65:208-209. https://doi.org/10.1007/BF00450594

Hinsinger P (2001) Bioavailability of soil inorganic P in the rhizosphere as affected by root-induced chemical changes: a review. Plant Soil 237:173-195. https://doi.org/10. 1023/A:1013351617532

Hodge A, Campbell CD, Fitter AH (2001) An arbuscular mycorrhizal fungus accelerates decomposition and acquires nitrogen directly from organic material. Nature 413:297299. https://doi.org/10.1038/35095041

Hofhansl F, Andersen KM, Fleischer K et al (2016) Amazon forest ecosystem responses to elevated atmospheric $\mathrm{CO} 2$ and alterations in nutrient availability: filling the gaps with model-experiment integration. Front Earth Sci 4:1-9. https://doi.org/10.3389/feart.2016.00019 
Hubau W, Lewis SL, Phillips OL et al (2020) Asynchronous carbon sink saturation in African and Amazonian tropical forests. Nature 579:80-87. https://doi.org/10.1038/ s41586-020-2035-0

Iversen CM, Ledford J, Norby RJ (2008) CO2 enrichment increases carbon and nitrogen input from fine roots in a deciduous forest. New Phytol 179:837-847. https://doi. org/10.1111/j.1469-8137.2008.02516.x

Jenkinson DS, Brookes PC, Powlson DS (2004) Measuring soil microbial biomass. Soil Biol Biochem 36:5-7. https://doi. org/10.1016/j.soilbio.2003.10.002

Jiang M (2020) The fate of carbon in a mature forest under carbon dioxide enrichment. Nature 580:227-231. https://doi. org/10.1038/s41586-020-2128-9

John TVS (1980) A survey of micorrhizal infection in an amazonian rain forest. Acta Amaz 10:527-533

Jones D, Hodge A, Kuzyakov Y (2004) Plant and mycorrhizal regulation of rhizodeposition. New Phytol 163:459-480. https://doi.org/10.1111/j.1469-8137.2004.01130.x

Jones D, Nguyen C, Finlay R (2009) Carbon flow in the rhizosphere: carbon trading at the soil-root interface. Plant Soil 321:5-33. https://doi.org/10.1007/s11104-009-9925-0

Jordan CF, Escalante G (1980) Root productivity in an Amazonian Rain Forest. Ecology 61:14-18. https://doi.org/10. 2307/1937148

Jordan CF, Herrera R (1981) Tropical rain forests: are nutrients really critical? Nat Resour. https://doi.org/10.1086/283696

Juma NG, Tabatabai MA (1988) Hydrolysis of organic phosphates by corn and soybean roots. Plant Soil 107:31-38. https://doi.org/10.1007/BF02371541

Keiluweit M, Bougoure JJ, Nico PS et al (2015) Mineral protection of soil carbon counteracted by root exudates. Nat Clim Chang 5:588-595. https://doi.org/10.1038/nclim ate 2580

Kuzyakov Y, Friedel JK, Stahr K (2000) Review of mechanisms and quantification of priming effects. Soil Biol Biochem 32:1485-1498. https://doi.org/10.1016/S00380717(00)00084-5

Laliberté E, Lambers H, Burgess TI, Wright SJ (2015) Phosphorus limitation, soil-borne pathogens and the coexistence of plant species in hyperdiverse forests and shrublands. New Phytol 206:507-521. https://doi.org/10.1111/ nph.13203

Lambers H, Martinoia E, Renton M (2015) Plant adaptations to severely phosphorus-impoverished soils. Curr Opin Plant Biol 25:23-31. https://doi.org/10.1016/j.pbi.2015.04.002

Lapola DM, Norby RJ (2014) Amazon FACE: Assessing the effects of increased atmospheric $\mathrm{CO} 2$ on the ecology and resilience of the Amazon forest. Science Plan \& Implementation Strategy

Lenth R, Singmann H, Love J et al (2020) Package 'emmeans.' R Packag version 115-15 34:216-221.https://doi.org/10. 1080/00031305.1980.10483031>.License

Liu R, Huang Z, Luke McCormack M et al (2016) Plasticity of fine-root functional traits in the litter layer in response to nitrogen addition in a subtropical forest plantation. Plant Soil 415:317-330. https://doi.org/10.1007/ s11104-016-3168-7

Lu M, Hedin LO (2019) Global plant-symbiont organization and emergence of biogeochemical cycles resolved by evolution-based trait modelling. Nat Ecol Evol 3:239-250. https://doi.org/10.1038/s41559-018-0759-0

Lugli LF, Andersen KM, Aragão LEOC et al (2020) Multiple phosphorus acquisition strategies adopted by fine roots in low-fertility soils in Central Amazonia. Plant Soil. https:// doi.org/10.1007/s11104-019-03963-9

Lugli LF, Rosa JS, Andersen KM et al (2021) Rapid responses of root traits and productivity to phosphorus and cation additions in a tropical lowland forest in Amazonia. New Phytol 0-1.https://doi.org/10.1111/nph.17154

Luizao FJ, Schubart HO (1987) Litter production and decomposition in a terra-firme forest of Central Amazonia. Experientia 43:259-265. https://doi.org/10.1007/BF019 45549

Luizão RC, Luizão FJ, Proctor J (2007) Fine root growth and nutrient release in decomposing leaf litter in three contrasting vegetation types in central Amazonia. Plant Ecol 192:225-236. https://doi.org/10.1007/s11258-007-9307-8

Malavolta E, Vitti GC, Oliveira AS (1989) Avaliação doestado nutricional das plantas: princípios e aplicações. Piracicaba

Marx MC, Wood M, Jarvis SC (2001) A microplate fluorimetric assay for the study of enzyme diversity in soils. Soil Biol Biochem 33:1633-1640. https://doi.org/10.1016/ s0038-0717(01)00079-7

McCormack ML, Iversen CM (2019) Physical and functional constraints on viable belowground acquisition strategies. Front Plant Sci 10:1-12. https://doi.org/10.3389/fpls. 2019.01215

McGill WB, Cole CV (1981) Comparative aspects of cycling of organic $\mathrm{C}, \mathrm{N}, \mathrm{S}$ and $\mathrm{P}$ through soil organic matter. Geoderma 26:267-286. https://doi.org/10.1016/00167061(81)90024-0

McGroddy ME, Silver WL, De Oliveira RC (2004) The effect of phosphorus availability on decomposition dynamics in a seasonal lowland amazonian forest. Ecosystems 7:172179. https://doi.org/10.1007/s10021-003-0208-y

Metcalfe DB, Williams M, Aragão LEOC et al (2007) A method for extracting plant roots from soil which facilitates rapid sample processing without compromising measurement accuracy: methods. New Phytol 174:697703. https://doi.org/10.1111/j.1469-8137.2007.02032.x

Moorhead DL, Sinsabaugh RL (2006) A theoretical model of litter decay and microbial interaction. Ecol Monogr 76:151-174. https://doi.org/10.1890/0012-9615(2006) 076[0151:ATMOLD]2.0.CO;2

Mooshammer M, Wanek W, Schnecker J et al (2012) Stoichiometric controls of nitrogen and phosphorus cycling in decomposing beech leaf litter. Ecology 93:770-782. https://doi.org/10.1890/11-0721.1

Mouginot C, Kawamura R, Matulich KL et al (2014) Elemental stoichiometry of fungi and bacteria strains from grassland leaf litter. Soil Biol Biochem 76:278-285. https://doi.org/ 10.1016/j.soilbio.2014.05.011

Murphy J, Riley J (1962) A modified single solution method for the determination of phosphate in natural waters. Anal Chim Acta 27:31-36. https://doi.org/10.1016/s00032670(00)88444-5

Nannipieri P, Giagnoni L, Landi L, Renella G (2011) Phosphorus in action 26:215-243. https://doi.org/10.1007/ 978-3-642-15271-9 
Nannipieri P, Giagnoni L, Renella G et al (2012) Soil enzymology: classical and molecular approaches. Biol Fertil Soils 48:743-762. https://doi.org/10.1007/s00374-012-0723-0

Oburger E, Jones DL, Wenzel WW (2011) Phosphorus saturation and $\mathrm{pH}$ differentially regulate the efficiency of organic acid anion-mediated $\mathrm{P}$ solubilization mechanisms in soil. Plant Soil 341:363-382. https://doi.org/10.1007/ s11104-010-0650-5

Olsen SR, Sommers L (1982) Methods of soil analysis: part 2 chemical and microbiological properties. In: American Society of Agronomy, Inc., Soil Science Society of America, pp 403-430

Olson JS (1963) Energy storage and the balance of producers and decomposers in ecological systems. Ecology 44:322331. https://doi.org/10.2307/1932179

Pan Y, Birdsey RA, Fang J et al (2011) A large and persistent carbon sink in the world's forests. Science 333:988-993. https://doi.org/10.1126/science.1201609

Parton W, Silver WL, Burke IC et al (2007) Global-scale similarities in nitrogen release patterns during long-term decomposition. Science (80- ) 80(315):361-364. https://doi.org/10. 1126/science. 1134853

Peguero G, Sardans J, Asensio D et al (2019) Nutrient scarcity strengthens soil fauna control over leaf litter decomposition in tropical rainforests. Proc R Soc B Biol Sci 1-9.https://doi. org/10.1098/rspb.2019.1300

Pereira IS, do Nascimento HEM, Vicari MB et al (2019) Performance of laser-based electronic devices for structural analysis of Amazonian terra-firme forests. Remote Sens 11:510. https://doi.org/10.3390/rs11050510

Phillips RP, Finzi AC, Bernhardt ES (2011) Enhanced root exudation induces microbial feedbacks to $\mathrm{N}$ cycling in a pine forest under long-term CO2 fumigation. Ecol Lett 14:187194. https://doi.org/10.1111/j.1461-0248.2010.01570.x

Powers JS, Montgomery RA, Adair EC et al (2009) Decomposition in tropical forests: a pan-tropical study of the effects of litter type, litter placement and mesofaunal exclusion across a precipitation gradient. J Ecol 97:801-811. https://doi.org/ 10.1111/j.1365-2745.2009.01515.x

Prescott CE (2010) Litter decomposition: What controls it and how can we alter it to sequester more carbon in forest soils? Biogeochemistry 101:133-149. https://doi.org/10.1007/ s10533-010-9439-0

Quéré C, Andrew R, Friedlingstein P et al (2018) Global carbon budget 2018. Earth Syst Sci Data 10:2141-2194. https://doi. org/10.5194/essd-10-2141-2018

Quesada CA, Lloyd J, Schwarz M et al (2010) Variations in chemical and physical properties of Amazon forest soils in relation to their genesis. Biogeosciences 7:1515-1541. https://doi.org/10.5194/bg-7-1515-2010

Quesada CA, Lloyd J, Anderson LO et al (2011) Soils of Amazonia with particular reference to the RAINFOR sites. Biogeosciences 8:1415-1440. https://doi.org/10.5194/bg-8-1415-2011

$\mathrm{R}$ Core T (2020) R: a language and environment for statistical computing

Saiya-Cork K, Sinsabaugh R, Zak D (2002) The effects of long term nitrogen deposition on extracellular enzyme activity in an Acer saccharum forest soil. Soil Biol Biochem 34:13091315. https://doi.org/10.1016/S0038-0717(02)00074-3
Sayer EJ, Tanner EVJ (2010) A new approach to trenching experiments for measuring root-rhizosphere respiration in a lowland tropical forest. Soil Biol Biochem 42:347-352. https:// doi.org/10.1016/j.soilbio.2009.11.014

Sayer EJ, Tanner EVJ, Cheesman AW (2006) Increased litterfall changes fine root distribution in a moist tropical forest. Plant Soil 281:5-13. https://doi.org/10.1007/s11104-005-6334-X

Schimel JP, Bennett J (2004) Nitrogen mineralization: challenges of a changing paradigm. Ecology 85:591-602

Sinsabaugh RL, Carreiro MM, Repert D (2002) Allocation of extracellular enzymatic activity in relation to litter composition, $\mathrm{N}$ deposition, and mass loss. Biogeochemistry 60:124. https://doi.org/10.1023/A:1016541114786

Siqueira JO, Carneiro MAC, Curi N et al (1998) Mycorrhizal colonization and mycotrophic growth of native woody species as related to successional groups in Southeastern Brazil. For Ecol Manage 107:241-252. https://doi.org/10.1016/S03781127(97)00336-8

Smith SE, Read DJ (2008) Mycorrhizal Symbiosis, 3rd Edn. Academic Press, San Diego and London, p 1-769

Soest PJV (1963) Use of detergents in the analysis of fibrous feeds. II. A rapid method for the determination of fiber and lignin. J Assoc Off Agric Chem 73:491-497. https://doi.org/ 10.1093/jaoac/73.4.491

Soong JL, Fuchslueger L, Marañon-Jimenez S et al (2020) Microbial carbon limitation: the need for integrating microorganisms into our understanding of ecosystem carbon cycling. Glob Chang Biol 26:1953-1961. https://doi.org/10. 1111/gcb.14962

Spohn M, Kuzyakov Y (2013) Distribution of microbial- and root-derived phosphatase activities in the rhizosphere depending on $\mathrm{P}$ availability and $\mathrm{C}$ allocation e Coupling soil zymography with $14 \mathrm{C}$ imaging. Soil Biol Biochem 67:106113. https://doi.org/10.1016/j.soilbio.2013.08.015

Stark NM, Jordan CF (1978) Nutrient retention by the root mat of an Amazonian Rain Forest. Ecology 59:434-437. https:// doi.org/10.2307/1936571

Terrer C, Prentice I, Jackson R et al (2019) Nitrogen and phosphorus constrain the $\mathrm{CO} 2$ fertilization of global plant biomas. Nat Clim Chang. https://doi.org/10.1038/ s41558-019-0545-2

Ushio M, Fujiki Y, Hidaka A, Kitayama K (2015) Linkage of root physiology and morphology as an adaptation to soil phosphorus impoverishment in tropical montane forests. Funct Ecol 29:1235-1245. https://doi.org/10.1111/13652435.12424

Vance ED, Nadkarni NM (1990) Microbial biomass and activity in canopy organic matter and the forest floor of a tropical cloud forest. Soil Biol Biochem 22:677-684. https://doi.org/ 10.1016/0038-0717(90)90015-R

Walker TW, Syers JK (1976) The fate of phosphorus during pedogenesis. Geoderma 15:1-19. https://doi.org/10.1016/ 0016-7061(76)90066-5

Wang W, Wu X, Hu K et al (2016) Understorey fine root mass and morphology in the litter and upper soil layers of three Chinese subtropical forests. Plant Soil 406:219-230. https:// doi.org/10.1007/s11104-016-2878-1

Welch SA, Taunton AE, Banfield JF (2002) Effect of microorganisms and microbial metabolites on apatite dissolution. 
Geomicrobiol J 19:343-367. https://doi.org/10.1080/01490 450290098414

Went F, Stark N (1968) THE biological and mechanical role of soil fungi. Botany 60:497-504. https://doi.org/10.1073/pnas. 60.2.497

Zangaro W, Nisizaki SMA, Domingos JCB, Nakano EM (2003) Mycorrhizal response and successional status in 80 woody species from south Brazil. J Trop Ecol 19:315-324. https:// doi.org/10.1017/S0266467403003341

Publisher's note Springer Nature remains neutral with regard to jurisdictional claims in published maps and institutional affiliations. 